ISWS C 81

loan copy

1

\title{
Circular 81
}

STATE OF ILLINOIS

WILLIAM G. STRATTON, Governor

DEPARTMENT OF REGISTRATION AND EDUCATION

VERA M. BINKS, Director

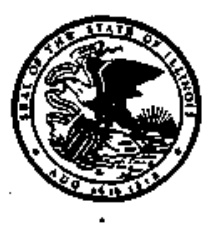

\section{Natural Radioactivity in Illinois Water Resources}

by T. E. LARSON and R. L. WEATHERFORD

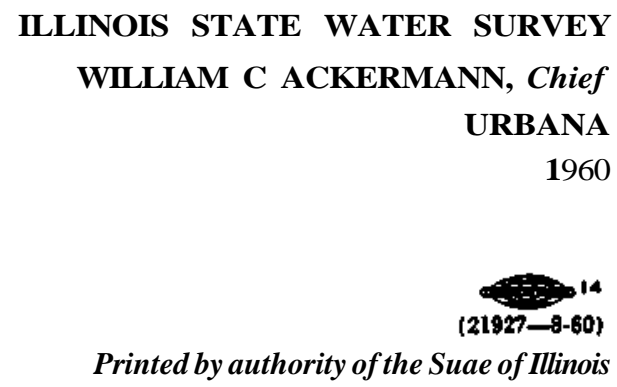




\section{Natural Radioactivity in Illinois Water Resources}

\section{-Thurston E. Larson and Richard L. Weatherford-}

A contribution to the Journal by Thurston E. Larson, Head, Chemistry Sec., and Richard L. Weatherford, Asst. Chemist, both of the State Water Survey Div., Urbana, Ill.

$\mathrm{V}$ ARIOUS isotopes have different levels of significance or limiting parameters of health hazard. Methods of radioactivity measurement vary, frequently from one laboratory to another, even to the extent that the measurements are often only roughly comparable. All radioactivity measurements at the Illinois State Water Survey, Urbana, Ill., made since May 1957 have been of samples of well waters, streams, and rivers. These measurements have been limited to gross alpha and beta activities by proportional counting of the nonvolatile residue remaining after evaporation of the water carrier. Such residues do not contain tritium, which will, therefore, not be discussed and which, furthermore, has a very low level of energy with a half-life of 12 years. It is of interest, however, as shown by Libby, ${ }^{1}$ that the beta activity of tritium in the Mississippi River was 5-20 $\mu \mu \mathrm{C} / 1$; in Lake Michigan, $5 \mu \mu \mathrm{C} / 1$; and in rainfall in the Midwest, approximately $20 \mu \mu \mathrm{C} / 1$.

For low levels of activity, an error of approximately 50 per cent was estimated with the levels of confidence shown in Table 1. Therefore, any appreciable confidence in results cannot be extended to activities of less than about $3 \mu \mu \mathrm{C} / 1$ (relative to 20 -min counting in duplicate for 250-ml samples). For 50 per cent confidence at an ac- tivity of $3 \mu \mu \mathrm{C} / \mathrm{l}$, a 2 -hr counting period would be required. Favorable limitations of the counting procedures are further degraded by the absence of specific information on the self-absorption that results from the deposition of neutral mineral salts from the samples containing nuclides responsible for radioactivity.

The physiologic significance of gross activity and specific radioactive isotopes, and the optimum and standard procedures for the determination of gross and specific activities, will not be discussed. Consideration will be given to: (1) the radioactivity of ground waters, which have been used as public supplies for more than four generations and which, for all practical purposes, contain only those isotopes of long halflives; (2) excerpts from, and interpretations of, data on $\mathrm{Ra}^{226}$ by Lucas and Ilcewicz ${ }^{2}$ of Argonne National Laboratories, Lemont, Ill.; and (3) data on gross activity of surface waters, with particular emphasis on measurements of gross dissolved beta radioactivity, with reference to the natural activity of Illinois water resources.

\section{Ground Water}

Since Jun. 1, 1957, about 300 well water samples have been examined for gross alpha and beta activities. When the data were assembled, waters known 
to be from the St. Peter or Galesville sandstones and three samples from Galena-Platteville dolomite, all from the Cambrian-Ordovician period, were grouped together. Then the waters from the Silurian and Devonian limestones were grouped together, as were the waters from the unconsolidated for- of beta activity, and the frequency of occurrence of activity at concentrations above any particular level was calculated. The beta activity was used because its magnitude was greater, in almost every instance, than the alpha activity, which, with relatively few exceptions, was negligible. The fre-

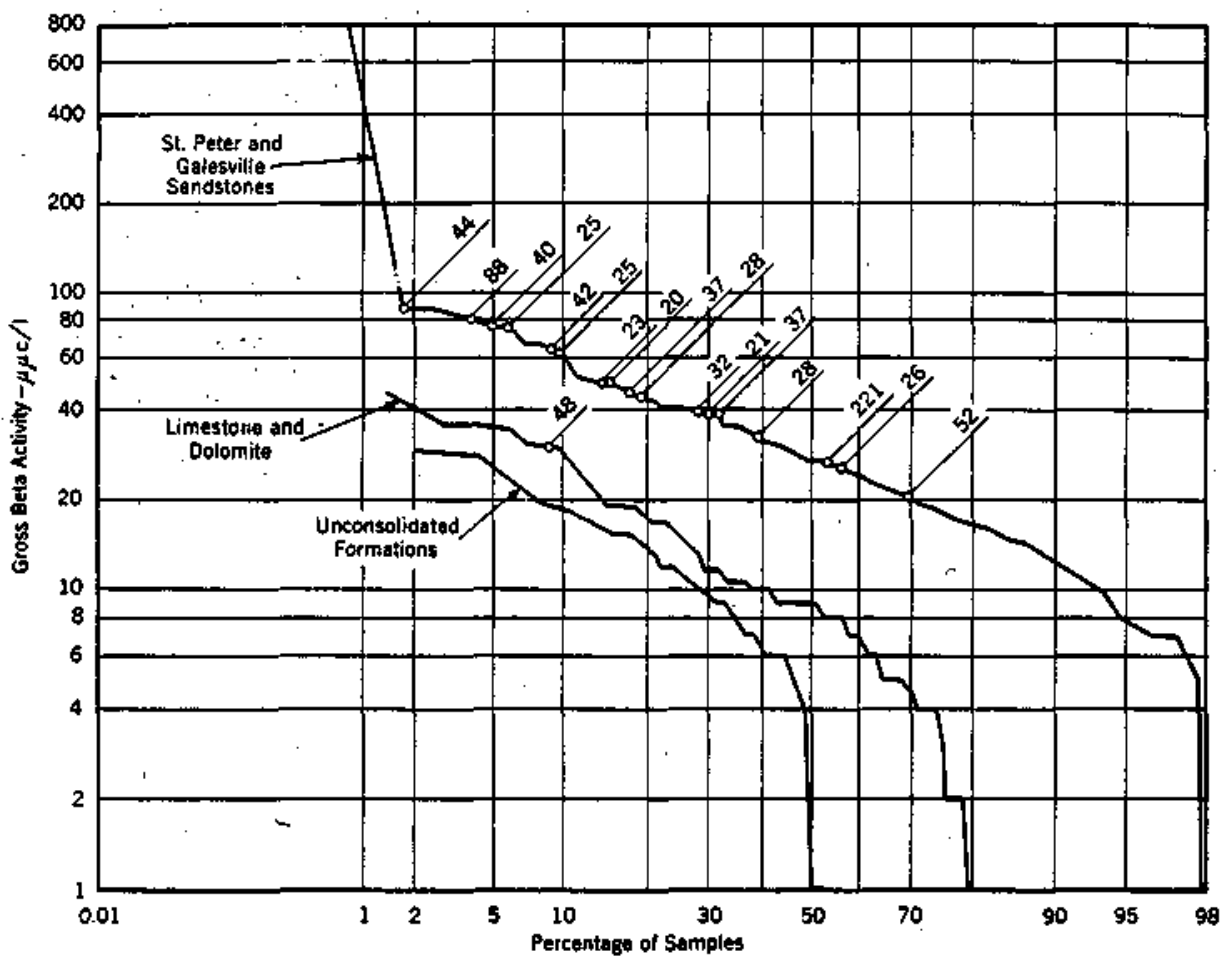

Fig. 1. Gross Activity of Ground Water

The numbers on the curves are the alpha activities (in micromicrocuries per liter) of eighteen samples with alpha activities exceeding $20 \mu \mu \mathrm{C} /$. A total of 49 samples from the unconsoliated formations was tested; 73 from the limestone and dolomite; and 126 from the St. Peter and Galesville sandstones.

inations in the glacial deposits and outwash or alluvium deposits. The remaining eleven samples represented waters from the sandstones and dolomites of the Mississippian and Pennsylvanian periods.

In each group of waters, the activities were ranked in order of the magnitude quency of occurrence of various levels of activity in ground waters is shown in Fig. 1.

Beginning with the top or unconsolidated formations above the bedrock, the level of activity for 49 samples was $1 \mu \mu \mathrm{c} / \mathrm{l}$ or less for 50 per cent of the samples; none of the samples showed an 
activity in excess of $30 \mu \mu \mathrm{C} / \mathrm{l}$. About 25 per cent of the samples exceeded an activity of $10 \mu \mu \mathrm{C} / 1$. The alpha activity did not exceed $8 \mu \mu C / 1$ in any sample, and exceeded $5 \mu \mu C /$ in only one. These data represent the normal range of activity for the waters from the glacial deposits, alluvium, and outwash along flowing streams. Although the four highest levels were from Illinoisan and Kansan glacial deposits, five other samples from the same sources had essentially no activity.

The number of samples from the Mississippian and Pennsylvanian periods were too few to be statistically significant, but the range of activities lay within the range of activity levels in the dolomites. These formations exist between the unconsolidated deposits and the Silurian or Devonian formations over the greater part of the state, but they are not particularly significant as a source of public water supplies.

The Devonian and Silurian dolomites and limestones are present below the coal measures and are important sources of public water supplies in the northern part of the state in the Rock Island area and in a strip extending from Iroquois County to the Wisconsin border. Of 73 samples, 20 per cent were found to have essentially no activity. Forty per cent had an activity of $10 \mu \mu \mathrm{C} / \mathrm{l}$ or more, and none exceeded $45 \mu \mu C$. . The ten highest levels of activity were from the Silurian dolomite, but because all except two of the thirteen lowest levels were also from the Silurian samples, there appears to be no distinguishing feature between waters of the Silurian and Devonian formations. The six known Devonian samples had a beta activity of $0-18$ $\mu \mu C /$. The alpha activities exceeded $10 \mu \mu \mathrm{C} / 1$ only three times, once to a level of $48 \mu \mu \mathrm{C} /$.
With regard to the greater number of the samples, these formations lie directly below the unconsolidated deposits. Therefore, it is reasonable to expect a hydrologic interrelationship between the two, accounting for the general similarity in the lower range of levels of activity.

For the data on waters of the Cambrian-Ordovician period from the St. Peter and Galesville sandstones, 126 samples showed a median beta activity of $28 \mu \mu \mathrm{c} \Lambda$. Of these samples, only two showed no activity and one an activity of more than $86 \mu \mu \mathrm{C} / \mathrm{l}$. There is only a slight difference between the activities of waters from the St. Peter and Galesville sandstones, as both waters are represented among

TABLE 1

Levels of Confidence for Low Levels of Radioactivity

$\begin{array}{cc}\text { Radioactivity } & \text { Level of Confidence } \\ \mu \mu c / l & \% \\ 15 & 95 \\ 9 & 83 \\ 6 & 62 \\ 3 & 30\end{array}$

those with the ten highest levels and the ten lowest levels of activity.

At locations west of the Illinois River, there appears to be a high proportion of these waters with higher levels of activity. St. Peter and Galesville waters are also usually characterized by the presence of significant alpha activity. The activities of seventeen samples with greater than $20 \mu \mu \mathrm{C} / \mathrm{l}$. alpha activity are plotted in Fig. 1 . Only 33 of the 126 samples showed less than $5 \mu \mu \mathrm{C} / 1$ alpha activity.

Several samples from one particular well gave considerable difficulty in duplicating results-perhaps, to some extent, owing to a total dissolved mineral content of 1,266 ppm. It did appear, however, that considerable alpha 
activity was present and, on recounts, the samples showed an increase in this activity between successive intervals of several months' storage. From these data it appears that at least 90 per cent of the samples showed a beta activity in the range of 10-90 $\mu \mu \mathrm{C} / \mathrm{l}$.

\section{Radium-226}

Lucas and Ilcewicz ${ }^{2}$ reported on $\mathrm{Ra}^{228}$ present in samples collected

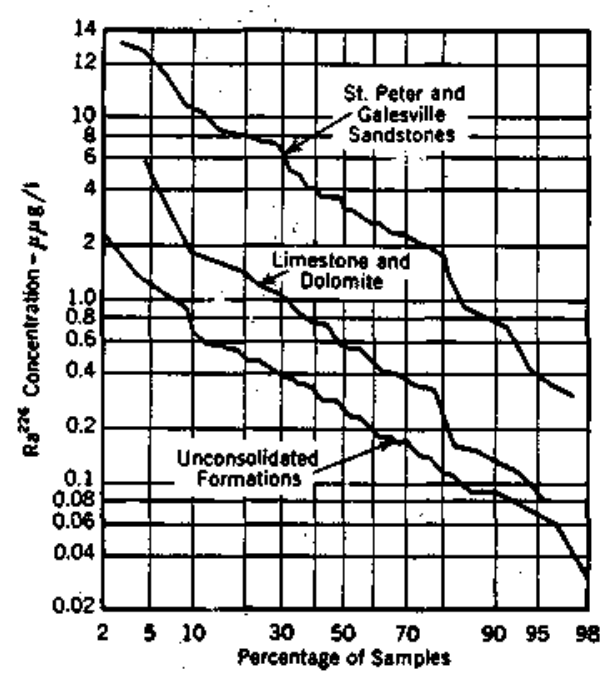

Fig. 2. Radium-226 in Municipal Well Waters

The median concentration of $\mathrm{Ra}^{226}$ for all wells that derive all or part of their water from the Cambrian-Ordovician and Precambrian periods was $3 \mu \mu \mathrm{g} / \mathrm{l}$.

from all communities in 51 randomly selected counties of the 102 counties in the state. Identification of sources of the well water supplies was made by the Illinois Water Survey from analyses of separate samples collected at each location. These data are shown in Fig. 2.

The average $\mathrm{Ra}^{226}$ content was 0.04 $\mu \mu g / 1$ for 28 surface water supplies, with a range of 0:00-0.15 $\mu \mu \mathrm{g} / \mathrm{l}$, which is in accordance with an average of $0.03 \mu \mu \mathrm{g} / \mathrm{l}$. found by $\mathrm{Hursh}^{2}$ for 35 major cities in the United States. The waters from the unconsolidated formations had a median concentration of $0.25 \mu \mu \mathrm{g} / \mathrm{l}$. Several of the very low values were from wells in the alluvium or outwash deposits, and the presence of nitrates indicated that these waters were from recent recharges. Waters from the Devonian and Silurian limestones showed a median concentration of $0.6 \mu \mu \mathrm{g} / \mathrm{l}$. The highest value represents water from a well located very near a St. Peter sandstone well that does not have the upper limestone formation cased off. Therefore, free movement of water between the two wells is known to occur. For limestone wells located in areas of sink holes, very low values were recorded; the waters probably were from recent recharges.

The Pennsylvanian sandstone waters were too few to be statistically important, but five of the six values for wells south of Alton and Lawrenceville had relatively high values. For the deep sandstone or the St. Peter and Galesville waters, some values were obtained from wells entering the Mt. Simon sandstone of the Precambrian period The six highest values, however, represent waters from the St. Peter sandstone. This fact is significant, but it was noted that six of the thirteen lowest values were also from the St. Peter sandstone. No Mt. Simon water sample exceeded a $\mathrm{Ra}^{228}$ content of $5 \mu \mu \mathrm{g} / \mathrm{l}$.

The median concentration of $\mathrm{Ra}^{228}$ for all wells that derive all or part of their water from the CambrianOrdovician and Precambrian periods was $3 \mu \mu g / l$. Although there is a similarity in the relative range of $\mathrm{Ra}^{226}$ activity as compared with the gross beta activity shown in Fig. 1, detailed 
examination indicated no direct correlation between the two. Lucas ${ }^{4}$ recently summarized data on Illinois populations using public supplies with various levels of $\mathrm{Ra}^{226}$ content (Table 2).

\section{Surface Water}

For the past $2 \frac{1}{2}$ years, USGS has cooperated with the Illinois Water Survey at jointly operated gaging stations in the collection of samples, once a month, from eighteen rivers in Illinois. The number and frequency of samples are not yet sufficient statistically to provide more than a general indication of the range of activities. Additional sam-

TABLE 2

Radium-226 Concentrations in Water Consumed by Illinois Populations

\begin{tabular}{|c|c|c|}
\hline Maximum Concentration & $\begin{array}{l}\text { Number } \\
\text { of Cities }\end{array}$ & Populationt \\
\hline $\begin{array}{c}0-0.99^{*} \\
1.0-3.9 \\
4.0-9.9 \\
10-37\end{array}$ & $\begin{array}{r}134 \\
42 \\
34 \\
19\end{array}$ & $\begin{array}{r}1,068,610 \\
213,532 \\
310,588 \\
30,261\end{array}$ \\
\hline
\end{tabular}

* Includes data on all tvoes of water source, in addl. tion to deep sandostone.

$\dagger+950$ census.

ples are being obtained from two sampling points at Crab Orchard Lake, from the Ohio River at Cairo, and from the Mississippi River at East St. Louis. Data are also available from biweekly samples taken since February 1958 from the Illinois River at the intake to the recharge pits at Peoria. These are taken most frequently and provide the greatest number of samples from a single location. Each of the surface water samples is examined for gross alpha and beta activities in the soluble form and also, by separate determinations, for activity in the suspended matter.
The data for the Illinois River at Peoria are shown in Fig. 3. In ranked order of magnitude of total activity, the median level was $40 \mu \mu \mathrm{C} / \mathrm{l}$, with 90 per cent of the samples in the range of 13-250 $\mu \mu \mathrm{C} / \mathrm{l}$ and 20 per cent containing more than $100 \mu \mu \mathrm{C} / \mathrm{l}$. It is of interest to note that the total activity is in no way related to the turbidity, for which corresponding values are also plotted in Fig. 3. It is perhaps also significant that the turbidity at this sampling point is rarely greater than $100 \mathrm{ppm}$. Direct treatment of suspended activity and suspended solids showed no consistent relationship to each other.

In general, high levels of total activity are associated with intense rainfall and streamflow (Fig. 4). There were two periods of dissolved activity (more than $100 \mu \mu C / 1)$ when this activity constituted the major portion of the total activity: in August 1958, for a period of about 5 weeks, and in March 1959, for a period of 2 weeks. After the first period, the high levels continued, even for lesser flows, for about 2 months. After the second period, the high levels continued for approximately 6 weeks.

Because reservoirs are designed to fill and hold runoff during periods of intense streamflow, such prolonged flow periods with high levels of dissolved activity could cause alarming conditions. The suspended activity would cause less difficulty, because regular clarification practices at treatment plants are designed to remove suspended matter.

Incidental to the collection of samples from the Illinois River, data on dissolved activity were also obtained in samples collected from a well located about $90 \mathrm{ft}$ from the recharge pits. Before June 1958, the dissolved activity for these samples was normally 
0-25 $\mu \mu C / 1$. Little change was noted during the summer of 1958, when recharging was not attempted; but, in February 1959, this activity increased to $30-60 \mu \mu C / 1$ during the period through April, and then returned to its previous level. These generalized data indicate incomplete removal of the activity by the soil during this recharge period when high-levels of dissolved ac- and rainfall, such excess activity may be recognized as the result of direct scrubbing of the atmosphere (rainout) and as the result of the washing of man-made structures, topsoil, and foliage by rainfall. Under current conditions, any dilution effect that rainfall may have is far outweighed by its pickup of activity before entering the stream. If this relationship continues

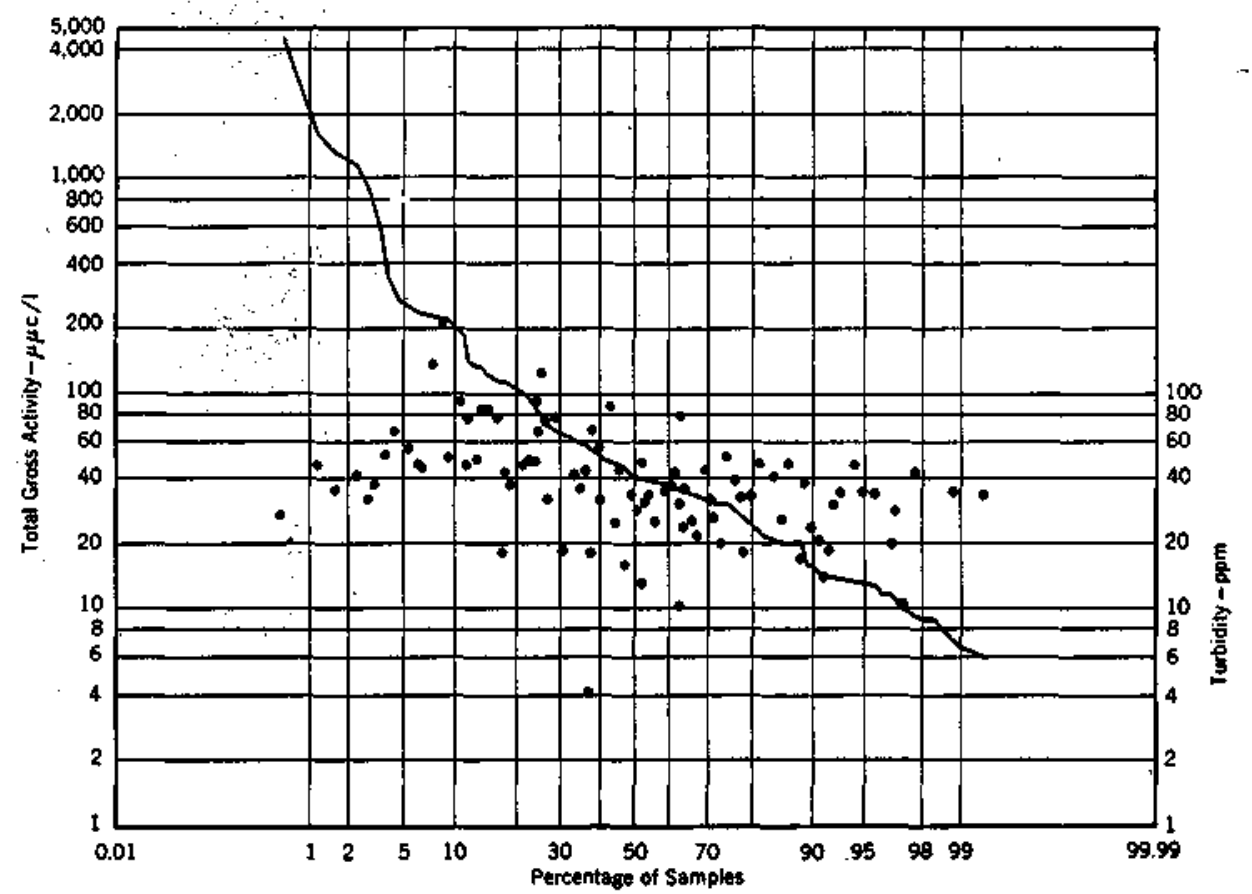

Fig. 3. Data on Illinois River at Peoria

The curve refers to the total gross activity; the circles, to turbidity. The data were collected during Jun. 28, 1957-Sep. 25, 1959.

tivity occurred in the river water. But the objective here is to consider natural activity; therefore, low levels of dissolved activity will be discussed in an attempt to evaluate the data to indicate the natural activity of the water.

\section{Dissolved Activity}

Because the high levels of activity are associated with intense streamflow through medium flow periods to minimum flow periods, the natural activity should be represented as that recorded at minimum flow periods after a long dry period. Accordingly, minimum activities have been observed in September and October, when the streamflow is at its natural minimum.

When the average daily dissolved activity passing the sampling point at the 
time of collection of each sample was calculated, it was noted that the minimum daily discharge of activity occurred during periods of less intense flow. The four lowest daily values were $91,000 \mu C, 49,000 \mu C 104,000 \mu C$ and $64,000 \mu C$.

In the watershed area, 58 mil gal of ground water was pumped daily for municipal and industrial use from the $\mu \mathrm{C} /$ day, and the pumpage of $21 \mathrm{mgd}$ from unconsolidated formations contributes $530 \mu \mathrm{C} /$ day. Thus, the ground water pumpage of $143 \mathrm{mgd}$ has an average activity of $16.3 \mu \mu \mathrm{C} / \mathrm{l}$ and contributes $8,760 \mu \mathrm{C} / \mathrm{day}$, with a contribution to the streamflow of $218 \mathrm{cfs}$. It is probable that about $2 \mathrm{cfs}$ is also being contributed by exposure of St. Peter sandstone to the river bottom from Ot-
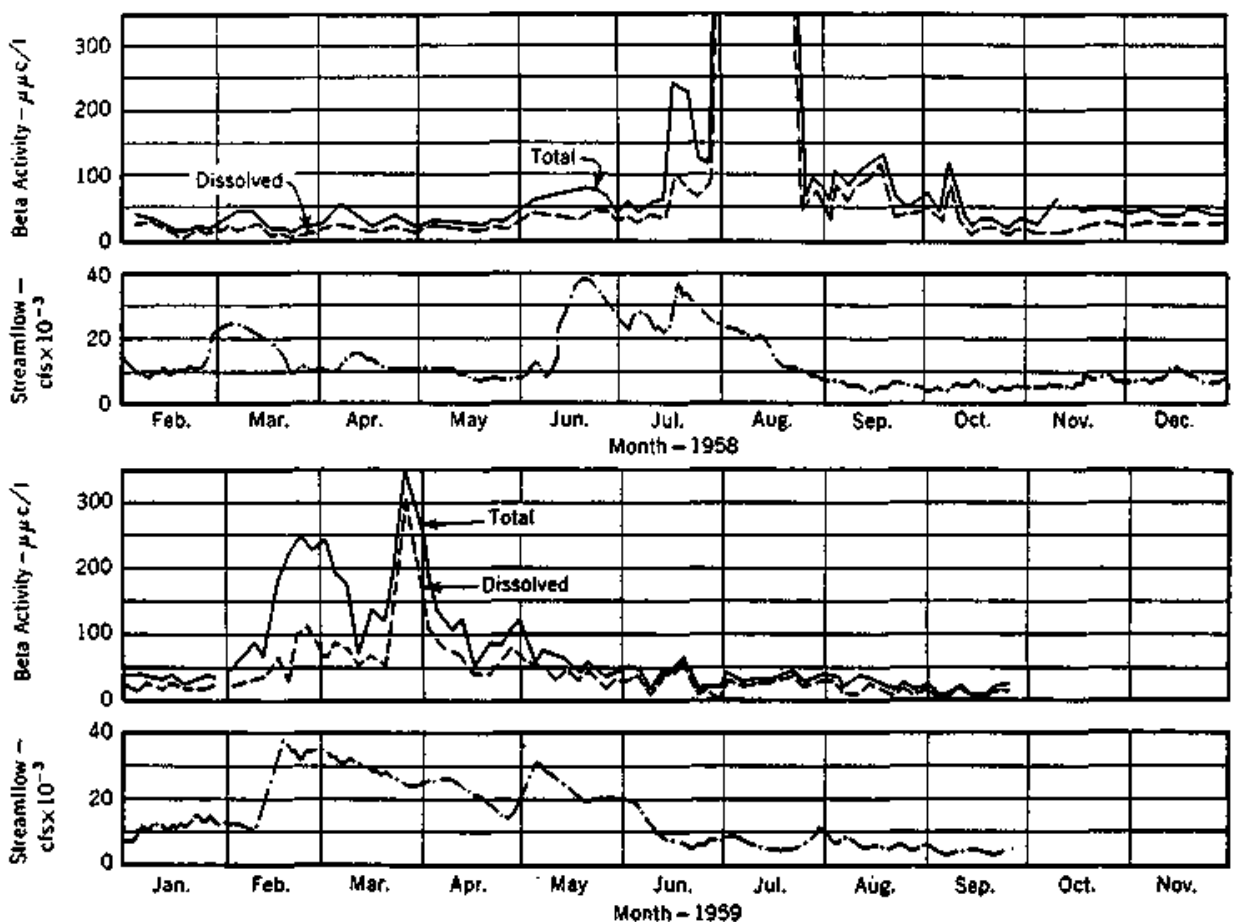

Fig. 4. Relationship Between Beta Activity and Streamflow

In general, the greater the streamflow, the greater the total activity.

deep sandstones (Cambrian-Ordovician and Precambrian periods). If it is assumed that percentages of this pumpage have beta activity indicated by the probability data in Fig. 1, the total dissolved beta activity contributed daily from this source to the streamflow of the Illinois River at Peoria is about $6,830 \mu C$. Likewise, the pumpage of 64 mgd from limestone contributes 1,400 tawa to LaSalle; nearly $140 \mu \mathrm{C} /$ day comes from this source. Thus, there is a total ground water contribution of about $8,900 \mu \mathrm{C} /$ day.

There are, of course, other ground water contributions from alluvial deposits along the streams of the watershed, but it is difficult to assume an activity for such waters. These waters, in large part, enter the formations dur- 
ing intense streamflow (and high levels of activity) by infiltration, but it is reported ${ }^{5-7}$ that the soils absorb some of the radioactive nuclides and serve as scavengers. This condition will pary to the extent that the nuclides remain fixed or subject to ion-exchange equilibria conditions. rainfall and runoff, would be 24,500 $\mu C /$ day, corresponding to a concentration of $3 \mu \mu C / 1$ in the combined water flow of $3,420 \mathrm{cfs}$. Thus, the activity of the runoff could be estimated by:

$$
A=\frac{B \times \mathrm{cfs} \times 2.44-24,500}{2.44\left(\mathrm{cfs}_{\mathrm{s}}-C+D\right)}
$$

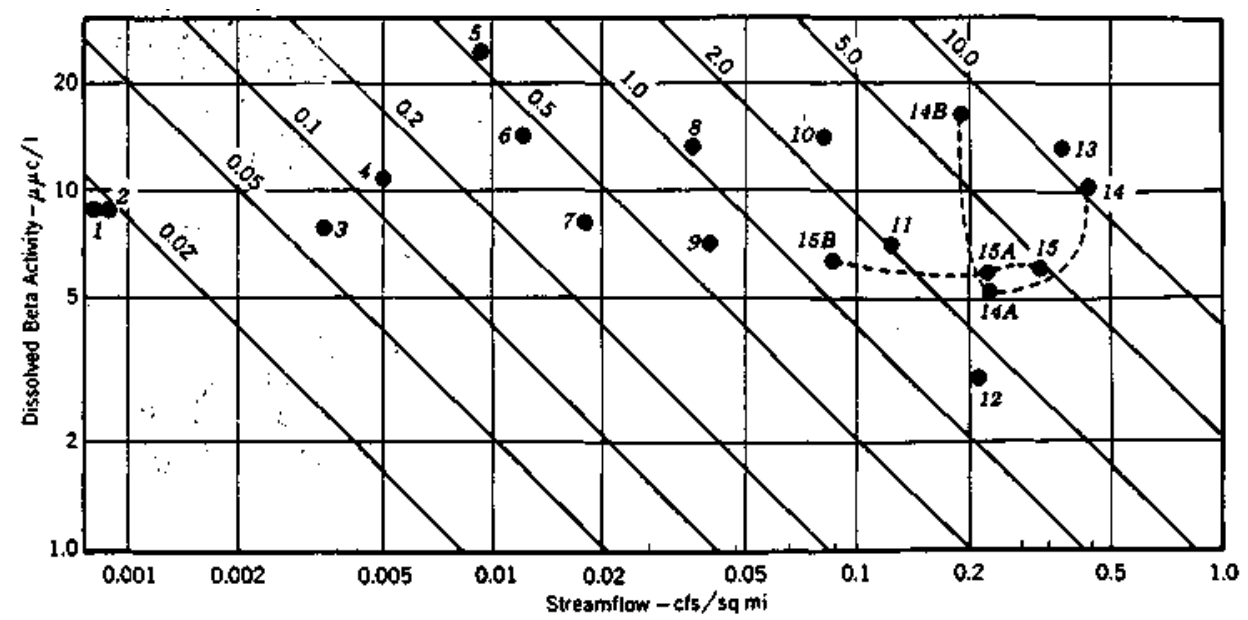

Fig. 5. Activity and Streamflow at Sampling Points

The numbered circles indicate the streams sampled \{the names of cities on stream where samples were collected are given in parentheses): 1, Cache; 2, Skillet Fork (Wayne City); 3, Kaskaskia (Shelbyville); 4, La Moine (Colmar); 5, Big Muddy (Murphysboro); 6, Little Wabash (Carmi); 7, Vermillion (Pontiac); 8, Fox (Dayton); 9, Kaskaskia (New Athens); 10, Mississippi River (E. St. Louis); 11, Fox (Algonquin); 12, Apple (Hanover); 13, Ohio River (Cairo); 14, Illinois River (Peoria, Sep. 24, 1959); 14A, ground water plus Lake Michigan contribution; 14B, runoff contribution; 15, Illinois River (Peoria, Sep. 10, 1959); 15A, ground water plus Lake Michigan contribution; and 15B, runoff contribution. The values on the curves represent minimum loads in microcuries per day per square mile. The tick marks on the abscissa refer to those samples assumed to have a beta activity of apapproximately $1 \mu \mathrm{C} / \mathrm{l}$.

The natural activity of Lake Michigan water has been reported to be approximately $2 \mu \mu \mathrm{C} / \mathrm{l}$. Therefore, if it is assumed that a flow of $1,700 \mathrm{cfs}$ is used by Chicago for its water supply and $1,500 \mathrm{cfs}$ is diverted, the total contribution of activity, including the known ground water contribution in the watershed from sources other than in which $\mathrm{A}$ is the dissolved beta activity of runoff (in micromicrocuries per liter) ; $B$, the beta activity of the sample (in micromicrocuries per liter); $C$, the flow of the Chicago water supply (in cubic feet per second); $D$, the diversion (in cubic feet per second); and cfs, the streamflow at the Peoria sampling point. 
In Table 3. the activity of the runoff is estimated for the samples representing the smallest discharges of activity in the Illinois River at Peoria.

For the two days of low activity load in September 1959, data on Chicago pumpage and Lake Michigan diversion were obtained to calculate more realistic data on the runoff activity. Prior to the sample taken on September 24-10 $\mu \mu C / 1$ at 5,900 cfs-the Chicago filtered-water pumpage was about 400 mgd with an average activity of 3.76 $\mu \mu C / 1$ and an unfiltered pumpage of 900 mgd, with an activity of about 4.4 $\mu \mu C / 1$. The lake diversion was reported to be $1,000 \mathrm{cfs}$ with $4.4 \mu \mu \mathrm{C} / \mathrm{l}$. This load was calculated to be 31,400 $\mu C /$ day, and, when added to 8,900 $\mu C /$ day from ground water, contributed $40,300 \mu C /$ day, with a total flow of 3,220 cfs or $5.15 \mu \mu C / 1$ as a basic load. The activity of the runoff was therefore calculated to be $15.9 \mu \mu C / 1$ for a 2,680cfs runoff.

Similarly, for the sample taken on September $10-6 \mu \mu C / 1$ at 4,400 cfs-the same pumpage and diversion conditions existed, but the average activity of filtered water was $3.96 \mu \mu \mathrm{C} / \mathrm{l}$ and the activity of raw lake water $5.8 \mu \mu \mathrm{C} / \mathrm{l}$. In this instance, the runoff activity was $6.5 \mu \mu \mathrm{C} / \mathrm{l}$ for $1,180 \mathrm{cfs}$.

This general approach to the evaluation of data to estimate the natural activity of streams takes into account the activity load of the stream and assumes dilution or mixing of the sources of activity with rainfall and runoff having no activity or a low level of activity. It was shown that a low level of recorded activity per unit volume may not be the natural activity when no contamination is present, because a large volume of flow with little activity can constitute a much greater activity load than a small volume of flow with more significant activity per unit volume.

This approach may be criticized for a number of reasons, but it must be recognized that the minimum recorded activity does not necessarily indicate the minimum activity that may occur. Dilution by activity-free water alone would alter the minimum activity parameter. A more serious limitation of the evaluation is in the inadequacy of the determination of dissolved beta activity, both in sensitivity and accuracy. Nevertheless, as the data are the best available, the same approach has been extended to the data for other streams in Illinois; for the purpose of

TABLE 3

Estimates of Runoff Activity in Illinois River at Peoria

\begin{tabular}{c|c|r|r|r}
\hline \hline Date & $\begin{array}{c}\text { Beta } \\
\text { Activity } \\
\mu \mu c / l\end{array}$ & $\begin{array}{r}\text { Stream- } \\
\text { flow } \\
c / s\end{array}$ & $\begin{array}{r}\text { Beta } \\
\text { Dis- } \\
\text { charge } \\
\mu c / \text { day }\end{array}$ & $\begin{array}{c}\text { Runoft } \\
\text { Attivity } \\
\mu \mu t / l\end{array}$ \\
\hline Mar. 23, 1958 & 4 & 9,300 & 91,000 & 4.5 \\
Mar. 26, 1958 & 2 & 10,100 & 49,000 & 1.5 \\
Oct. 26, 1958 & 8 & 5,300 & 104,000 & 15.3 \\
Sep. 10, 1959 & 6 & 4,400 & 64,000 & 13.6 \\
Sep. 10, 1959 & 6 & 4,400 & 64,500 & 6.5 \\
Sep. 24, 1959 & 10 & 5,900 & 144,000 & 15.9 \\
\hline
\end{tabular}

comparison, the streamflow is expressed in cubic feet per second per square mile. Thus, for a particular determined activity of a sample collected for a recorded streamflow, the load may be calculated in microcuries per day per square mile of watershed, and any dilution by nonactive water will decrease the measured activity in accordance with the increase in streamflow, but without change in the activity load. Also, any increase in load greater than the minimum recorded load can be related to a calculated activity of the additional streamflow or runoff. 
The recorded activity and corresponding streafnflow for samples representing the minimum calculated load at sampling points are shown in Fig. 5. For the Big Muddy River, the minimin load was represented by a sample of $24 \mu \mu \mathrm{C} / 1$, although other samples showed $10 \mu \mu C / 1$ or less, but at greater streamflows and corresponding loads.

Of approximately SSO samples, 11 samples were found to contain no dissolved beta activity. These findings occurred in only one or two samples from each of 9 of the 23 sampling points. In view of the limitations in sensitivity and precision of the determinations, these samples might be assumed to have an activity of $1 \mu \mu \mathrm{C} / 11$ or slightly more. The minimum loads in these instances are indicated by tick marks at the 1.0 $\mu \mu C / 11$ level in Fig. 5 .

For sixteen samples each from the Ohio River and the Mississippi River, the largest watersheds, the respective minimum loads were 11.4 and 2.56 $\mu \mathrm{C} / \mathrm{day} / \mathrm{sq} \mathrm{mi}$, and the respective activity levels were 14 and $13 \mu \mu C / 1$. The range of data indicates that the minimum load in Illinois streams is certainly less than $10 \mu \mathrm{C} / \mathrm{day} / \mathrm{sq} \mathrm{mi}$, and in sixteen of nineteen streams (about 84 per cent) other than the Illinois River, the recorded minimum load was less than $1.0 \mu \mathrm{C} / \mathrm{day} / \mathrm{sq} \mathrm{mi}$. Twentyfive per cent of the streams have had a load less than $0.1 \mu \mathrm{C} / \mathrm{day} / \mathrm{sq} \mathrm{mi}$; and 10 per cent, less than $0.01 \mu \mathrm{C} / \mathrm{day} / \mathrm{sq} \mathrm{mi}$.

As a general observation, the minimum recorded load increases with increasing watershed area, owing to sustained flow contributed by runoff. The lower levels of sustained load usually appear to be associated with periods of low volume of flow for the smaller watersheds, where the sustained flow is primarily the result of ground water contribution from unconsolidated materials.

Finally, it should be recognized that the minimum recorded activities for Illinois streams and, in many instances, the corresponding minimum load as natural activity are less than the sensitivity and accuracy of the current methods of measurement of gross alpha and beta activity by proportional counters.

\section{Acknowledgment}

The authors wish to express their appreciation to David Gray for his assistance in recording and assembling the data for this article.

\section{References}

1. LIBBY, W. F. Potential Usefulness of Natural Tritium. Proc. Nat. Acad. Sci. US, 39:245 (1953).

2. LUCAS, H. F., JR. \& ILCEWICZ, F. H Natural Radium-226 Content of Illinois Water Supplies. Jour. AWWA, 50:1523 (Nov. 1958).

3. HURSH, J. B. Radium Content of Public Water Supplies. USAEC Rept. UR-257, Univ. of Rochester, Rochester, N.Y. (1953).

4. LUCAS, H. F. Populations Consuming Water With High Natural Radium-226 Content. Argonne National Laboratory Report 6049, Lemont, Ill. (1959).

5. EWING, B. B. Field Test of the Movement of Radioactive Cations. Proc. ASCE, 85:39 (1959).

6. BARKER, F. B. Factors Affecting the Transport of Radioactivity by Water. Jour. AWWA, 50:603 (May 1958).

7. NISHITA, H.; KOWALESKY, B. W.; \& LARSON, K. H. Fixation and Extractability of Fission Products Contaminating Various Soils and Clays: I, $\mathrm{Sr}^{89} \mathrm{Sr}^{90}$, $\mathrm{Y}^{91}, \mathrm{Ru}^{106}, \mathrm{Cs}^{137}$, and $\mathrm{Ce}^{144}$. USAEC Publication 282, Univ. of California, Berkeley, Calif. (1954). 


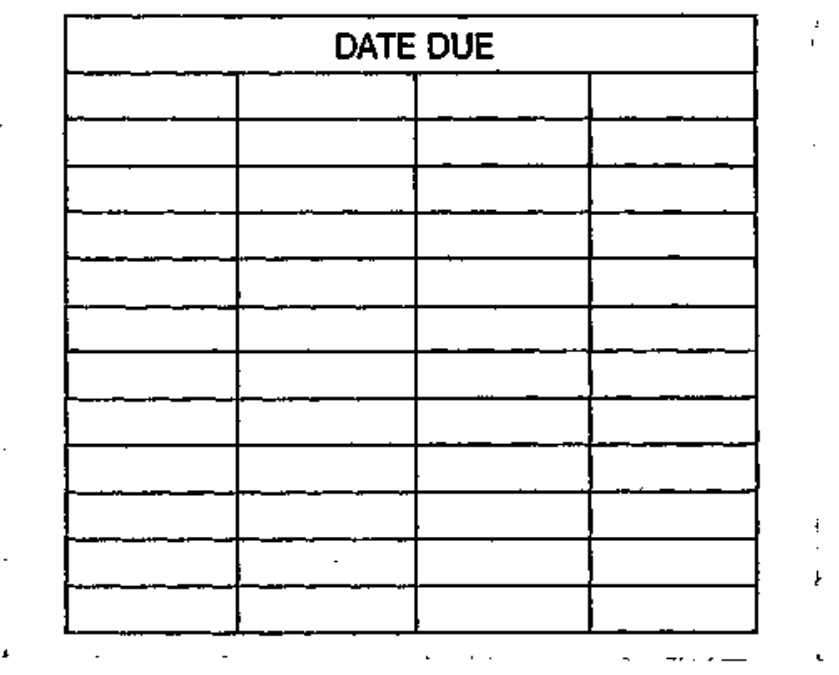

ISWS C81 Larson, Thurston E. loan copy NATURAL RADIOACTrVITY IN 1 ILLINOIS WATER RESOURCES 